\title{
Effect of Reactive and Non-Reactive Diluent on Mechanical Properties of Epoxy Resin
}

\section{Reaktif ve Reaktif Olmayan Seyreltici İlavesinin Epoksinin Mekanik Özelliklerine Etkisi}

\author{
Ömür Aras ${ }^{1}$, Yunus Kaya ${ }^{2 *}$ \\ Geliş / Received: 07/01/2021 \\ Revize / Revised: 24/01/2021 \\ Kabul / Accepted: 01/02/2021

\begin{abstract}
Epoxy resins, which are frequently preferred among thermoset plastics in the industry, are materials with high viscosity, and good mechanical performance. The biggest disadvantage of epoxy resins is that they encounter difficulties in application alone due to their high viscosity. For this reason, various diluents are added to reduce their viscosity and applications are conducted. In this study, the mechanical properties of the epoxy resin, which is used in many fields, were observed with the addition of certain sizes of reactive and non-reactive diluents. Diglycidyl ether was used as the reactive diluents, and benzyl alcohol was used as the non-reactive diluent. In addition, ethylene diamine and diethylene triamine were used as curing agents. It was tried to determine the optimum modification of the hardened epoxy resin by measuring the mechanical strengths in the electromechanical test device. The results indicated the optimum composition that does not dramatically affect the mechanical performance of the epoxy resin is the composition containing 7.5\% DE and 10\% EDA, its tensile strength measured as $53.27 \mathrm{~N} / \mathrm{mm}^{2}$.
\end{abstract}

Keywords- Epoxy Resin, Viscosity, Mechanical Properties, Reactive and Non-Reactive Diluent

$\underline{\text { öZ }}$

Endüstride termoset plastikler arasında sıklıkla tercih edilen epoksi reçineler yüksek viskoziteye sahip, mekanik performansları oldukça iyi olan malzemelerdendir. Epoksi reçinelerinin en büyük dezavantajı, yüksek viskoziteleri sebebiyle tek başlarına uygulamada zorluklar ile karşılaşılmasıdır. Bu nedenle, viskozitelerini düşürmek amacıyla çeşitli diluentler eklenerek uygulamaları yapılmaktadır. Bu çalışma kapsamında birçok alanda kullanılan epoksi reçinenin, belirli ölçülerde reaktif ve reaktif olmayan seyreltici ilavesiyle mekanik özelliğindeki değişmeler gözlendi. Çalışmada reaktif diluent olarak diglisidil eter, non-reaktif diluent olarak ise benzil alkol kullanıldı. Kürleme ajanı olarak ise etilen diamin ve dietilen triamin kullanıldı. Sertleştirilmiş epoksi reçinenin elektromekanik test cihazında mekanik dayanımınları ölçülerek optimum modifikasyonu belirlenmeye çalışıldı. Elde edilen sonuçlar, epoksi reçinesinin mekanik performansını önemli ölçüde etkilemeyen optimum bileşimin \% $7.5 \mathrm{DE}$ ve \% 10 EDA içeren bileşim olduğunu, bu numunenin gerilme mukavemetinin $53.27 \mathrm{~N} / \mathrm{mm}^{2}$ olarak ölçüldüğünü gösterdi.

Anahtar Kelimeler- Epoksi Reçinesi, Viskozite, Mekanik Özellik, Reaktif ve Reaktif Olmayan Seyreltici

1İletişim: omur.aras@btu.edu.tr (https://orcid.org/0000-0003-4577-028X)

Kimya Mühendisliği Bölümü, Bursa Teknik Üniversitesi, Mühendislik ve Doğa Bilimleri Fakültesi, Bursa, Türkiye

${ }^{2 *}$ Sorumlu yazar iletişim: yunus.kaya@btu.edu.tr (https://orcid.org/0000-0001-7228-2340)

Kimya Bölümü, Bursa Teknik Üniversitesi, Mühendislik ve Doğa Bilimleri Fakültesi, Bursa, Türkiye 


\section{INTRODUCTION}

Diglycidyl ether of bisphenol (DGEBA) A is the most used epoxy and its viscosity varies depending on the number of repeating units (n) and molecular weight (Figure 1).

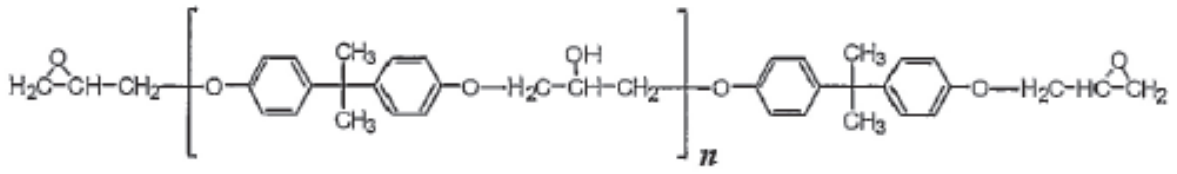

Figure 1. Molecular strucute of epoxy resin (DGEBA)

While the use of epoxy resins as binders for many materials is the biggest advantage, their high viscosity is their biggest disadvantage. As such, it represents a promising field of material research. It is known that the addition of reactive or non-reactive diluents in certain proportions by weight reduces the strength of binders relatively, and thus, a certain reduction in the strength of the cured product is observed by further increasing the diluent content [1-5]. Great emphasis is placed on the use of reactive diluents and modifiers that cause effective changes in the polymerization step as well as reduce viscosity effectively $[1,6]$. Study of these diluents is necessary because of both practical problems and very limited knowledge of the effect of diluent addition on the chemical and physical properties of epoxy polymers [7]. On the other hand, these diluents cost much more than non-reactive diluents. Therefore, it is useful to perform an optimum study in which reactive and non-reactive diluents coexist.

In this study, the epoxy resin synthesized in the laboratory $\left(E_{w}=195 \mathrm{~g} / \mathrm{mol}\right)$, glycidyl ether as the reactive diluent, benzyl alcohol as the non-reactive diluent and ethylene diamine and diethylene triamine as curing agents were used (Figure 2).<smiles>C(OCC1CO1)C1CO1</smiles>

Diglycidyl ether<smiles>OCc1ccccc1</smiles>

Benzyl alcohol<smiles>NCCN</smiles>

Ethylene diamine<smiles>NCCNCCN</smiles>

Diethylene triamine

Figure 2. Molecular strucute of glycidyl ether, benzyl alcohol, ethylene diamine and diethylene triamine

\section{EXPERIMENTAL METHOD}

The epoxy resin used in this study is diglycidyl ether of bisphenol A (DGEBA) was synthesized as literature procedure [8]. The glycidyl ether, benzyl alcohol, ethylene diamine, and diethylene triamine are the most widely used diluents, and hardener were purchased from sigma and used without purification. The amounts of hardeners are determined from the stoichiometry calculations of DGEBA and amines. The amounts of hardener and diluents using in this study are listed in Table 1. All samples created by mixing at the rates listed in Table 1 were poured onto silicone molds. Samples were kept at room temperature during gelling. The samples that started to gel, the samples placed in the oven set at $70{ }^{\circ} \mathrm{C}$ were kept here for 24 hours. Mechanical properties of epoxy samples were examined by using tensile tester (Shimadzu AGS-X Series), elastic modulus and percent (\%) elongation values were determined. Tensile tests $2 \mathrm{~mm} / \mathrm{min}$. It was carried out at room temperature at drawing speed. In addition, the viscosities of the resin and diluent mixtures were measured using a Brookfield viscometer. 


\begin{tabular}{|c|c|c|}
\hline & $\begin{array}{l}\text { BŞEÜ Fen Bilimleri Dergisi } \\
8(1), 167-172,2021\end{array}$ & $\begin{array}{r}\text { BSEU Journal of Science } \\
\text { https://doi.org/10.35193/bseufbd.855955 }\end{array}$ \\
\hline & & 2458-7575 (https://dergipark.org.tr/tr/pub/bseufbd) \\
\hline
\end{tabular}

Table 1. The amounts of hardener and diluents for each sample

\begin{tabular}{|c|c|c|c|c|}
\hline \multirow[b]{2}{*}{ Samples } & \multicolumn{2}{|c|}{ Diluents (\%) } & \multicolumn{2}{|c|}{ Hardener (\%) } \\
\hline & Diglycidyl ether (DE) & Benzyl alcohol (BA) & $\begin{array}{c}\text { Ethylene diamine } \\
\text { (EDA) }\end{array}$ & $\begin{array}{l}\text { Diethylene triamine } \\
\text { (DETA) }\end{array}$ \\
\hline 1 & - & - & 10.0 & - \\
\hline 2 & 10.0 & - & 10.0 & - \\
\hline 3 & - & 10.0 & 10.0 & - \\
\hline 4 & 10.0 & 10.0 & 10.0 & - \\
\hline 5 & - & - & - & 10.0 \\
\hline 6 & 10.0 & - & - & 10.0 \\
\hline 7 & - & 10.0 & - & 10.0 \\
\hline 8 & 10.0 & 10.0 & - & 10.0 \\
\hline 9 & 5.0 & - & 10.0 & - \\
\hline 10 & - & 5.0 & 10.0 & - \\
\hline 11 & 5.0 & 5.0 & 10.0 & - \\
\hline 12 & 5.0 & - & - & 10.0 \\
\hline 13 & - & 5.0 & - & 10.0 \\
\hline 14 & 5.0 & 5.0 & - & 10.0 \\
\hline 15 & 2.5 & - & 10.0 & - \\
\hline 16 & - & 2.5 & 10.0 & - \\
\hline 17 & 2.5 & 2.5 & 10.0 & - \\
\hline 18 & 2.5 & - & - & 10.0 \\
\hline 19 & - & 2.5 & - & 10.0 \\
\hline 20 & 2.5 & 2.5 & - & 10.0 \\
\hline 21 & 7.5 & - & 10.0 & - \\
\hline 22 & - & 7.5 & 10.0 & - \\
\hline 23 & 7.5 & 7.5 & 10.0 & - \\
\hline 24 & 7.5 & - & - & 10.0 \\
\hline 25 & - & 7.5 & - & 10.0 \\
\hline 26 & 7.5 & 7.5 & - & 10.0 \\
\hline
\end{tabular}

\section{RESULTS AND DISCUSSION}

Epoxy resin was synthesized as written in the literature [8], and characterized by FTIR and NMR measurements. The viscosity of the synthesized DGEBA resin was measured $16200 \mathrm{cp}$. In addition, the equivalent epoxide weight (EEW) value of the synthesized epoxy was calculated as $206 \mathrm{~g} /$ equv from the NMR spectrum. Dilution was applied to make this resin applicable in industry. Twelve different epoxy mixtures were obtained by adding diluents in different proportions. The viscosity variations of DGEBA resin containing different amounts of the diluents, diglycidyl ether and benzyl alcohol are shown in Figure 3. With the addition of diluent, viscosities drop as expected. The highest viscosity is observed in pure epoxy resin. In addition, the viscosity value obtained by adding the same proportion of benzyl alcohol was measured lower than the addition of diglycidyl ether [9].

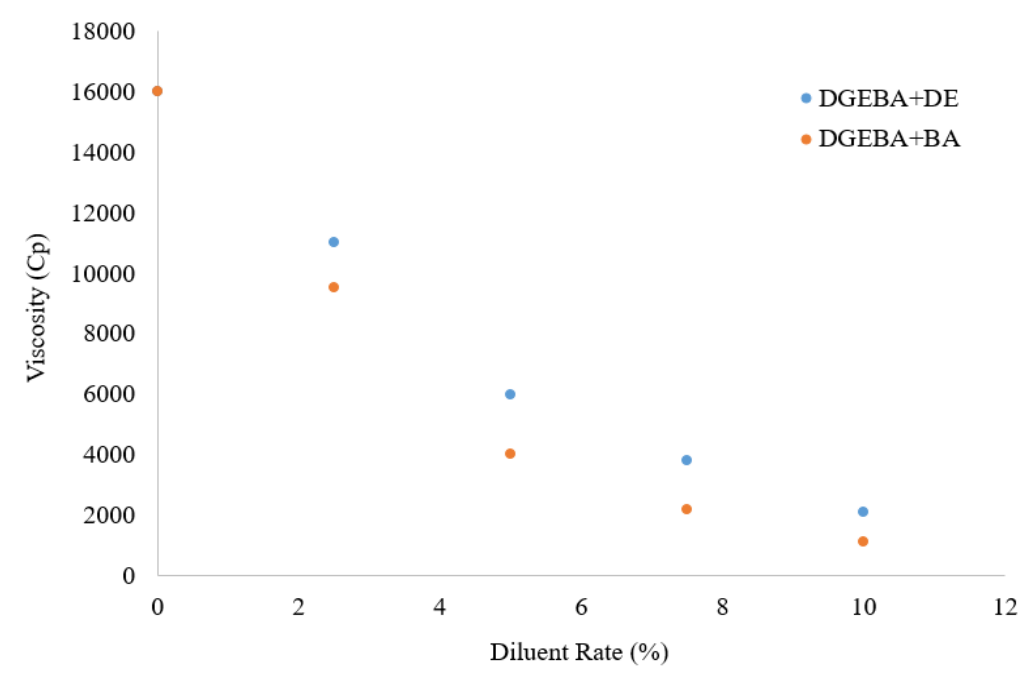

Figure 3. Variation of viscosity of resin with diluents rate 
The mechanical properties of DGEBA resins (i.e. tensile strength $\sigma$, elastic module $\mathrm{E}$ and strain at break $\varepsilon)$ were determined from tensile tests. The tensile stress-strain curves of pure DGEBA resin cured with amines, EDA (1) and DETA (5) were given in Figure 4. In addition, the mechanical properties of the 26 samples obtained by adding diluents in different ratios are listed in Table 2 . The tensile stress-strains of pure DGEBA, 1 and 5 were measured at 68.20 and $60.75 \mathrm{~N} / \mathrm{mm}^{2}$, respectively. In general, the addition of diluents reduced both tensile strength $\sigma$ and elastic module E.

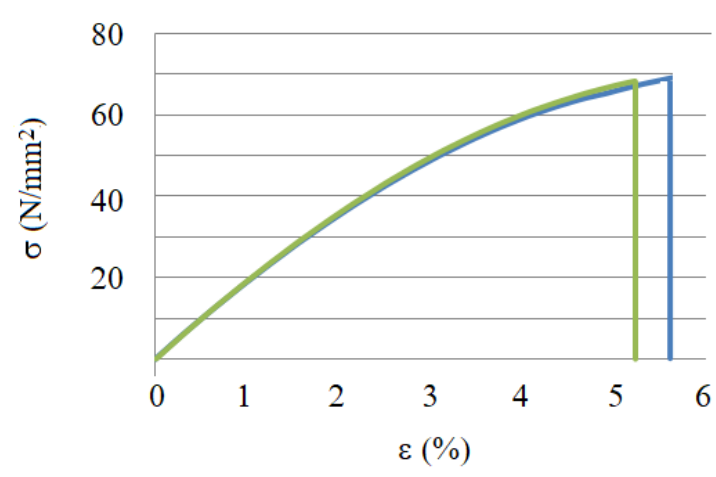

(a)

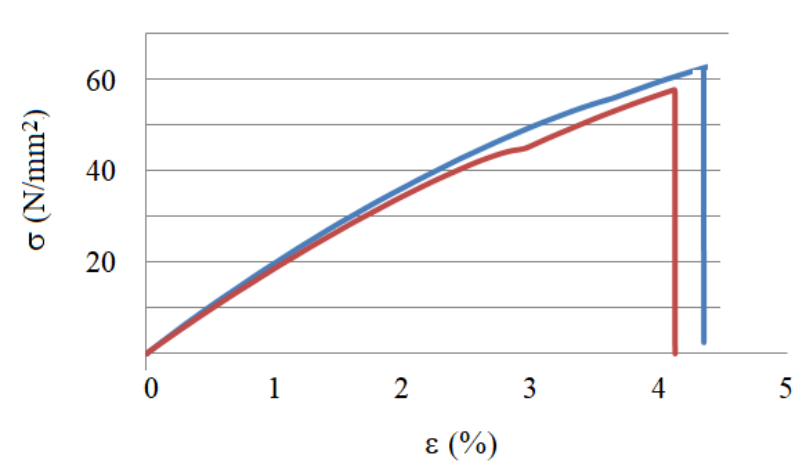

(b)

Figure 4. Stress-strain curves of the pure epoxy resin with curing (a) EDA (b) DETA

Table 2. Mechanical properties of DGEBA resins with different diluents and hardeners.

\begin{tabular}{|c|c|c|c|}
\hline Samples & $\begin{array}{c}\text { Tensile strength, } \sigma \\
\left(\mathbf{N} / \mathbf{m m}^{2}\right)\end{array}$ & $\begin{array}{c}\text { Strain at break, } \varepsilon \\
(\%)\end{array}$ & $\begin{array}{c}\text { Elastic module, } \mathrm{E} \\
\left(\mathrm{N} / \mathrm{mm}^{2}\right)\end{array}$ \\
\hline 1 & 68.20 & 5.68 & 1974.14 \\
\hline 2 & 52.71 & 4.57 & 1912.27 \\
\hline 3 & 47.97 & 5.75 & 1743.89 \\
\hline 4 & 14.46 & 20.28 & 880.68 \\
\hline 5 & 60.75 & 4.34 & 2046.97 \\
\hline 6 & 46.47 & 5.42 & 1617.36 \\
\hline 7 & 37.87 & 5.93 & 1781.31 \\
\hline 8 & 25.46 & 11.79 & 1080.16 \\
\hline 9 & 53.27 & 7.19 & 1787.13 \\
\hline 10 & 49.22 & 5.72 & 1916.44 \\
\hline 11 & 41.48 & 4.67 & 1850.53 \\
\hline 12 & 51.29 & 3.52 & 1937.26 \\
\hline 13 & 50.26 & 4.12 & 2088.49 \\
\hline 14 & 49.56 & 5.50 & 1787.62 \\
\hline 15 & 60.67 & 5.35 & 1852.99 \\
\hline 16 & 48.59 & 4.42 & 1910.55 \\
\hline 17 & 50.83 & 4.26 & 1946.28 \\
\hline 18 & 59.31 & 6.13 & 1846.11 \\
\hline 19 & 48.45 & 4.37 & 1817.69 \\
\hline 20 & 55.30 & 6.46 & 1899.37 \\
\hline 21 & 53.36 & 4.44 & 1938.07 \\
\hline 22 & 38.25 & 4.42 & 1817.02 \\
\hline 23 & 20.74 & 7.64 & 1348.69 \\
\hline 24 & 48.00 & 3.91 & 1818.94 \\
\hline 25 & 26.72 & 2.01 & 1764.20 \\
\hline 26 & 32.26 & 5.09 & 1583.01 \\
\hline
\end{tabular}




\begin{tabular}{|c|c|c|}
\hline & $\begin{array}{l}\text { BŞEÜ Fen Bilimleri Dergisi } \\
8(1), 167-172,2021\end{array}$ & $\begin{array}{r}\text { BSEU Journal of Science } \\
\text { https://doi.org/10.35193/bseufbd.855955 }\end{array}$ \\
\hline & & 2458-7575 (https://dergipark.org.tr/tr/pub/bseufbd) \\
\hline
\end{tabular}

The tensile stresses of different samples are compared in Figure 5 (a) and (b). Figure 5 (a) shows the variation of tensile stress with the addition of $10 \% \mathrm{DE}, \mathrm{BA}$, and both. With the addition of $10 \% \mathrm{DE}$ and $\mathrm{BA}, 52.71$ and $47.97 \mathrm{~N} / \mathrm{mm}^{2}$ were measured, respectively. It was observed that the addition of BA decreased the stress more than the addition of DE. With the addition of both diluents the value dropped to $14.46 \mathrm{~N} / \mathrm{mm}^{2}$. When Figure 5 (b) is examined, it is seen that the tensile stress of the samples with more diluent added by mass decreases. When the graph is examined, the highest tensile stress was observed with $60,67 \mathrm{~N} / \mathrm{mm}^{2}$ in the sample 5 . The difference between samples 1 and 5 is due to the curing agent. The samples 15, 9, 21 and 2 are samples diluted with 2.5, 5, 7.5 and $10 \% \mathrm{DE}$, respectively, and the tensile stresses of these samples were measured as $60.67,53.27,53.36$ and $52.71 \mathrm{~N} / \mathrm{mm}^{2}$, respectively. According to these results, with the use of both reactive and non-reactive diluents, the tensile stress decreases with increasing the number of diluents [10].

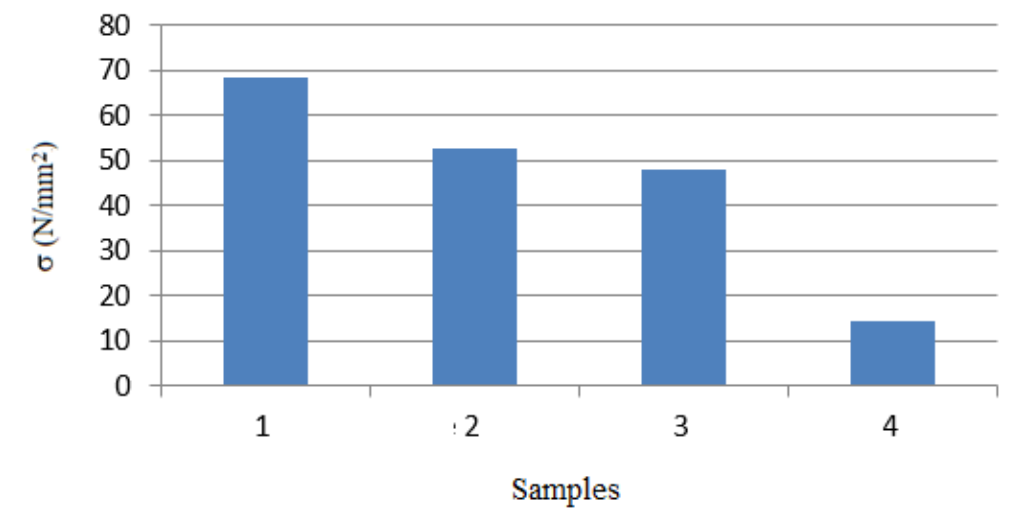

(a)

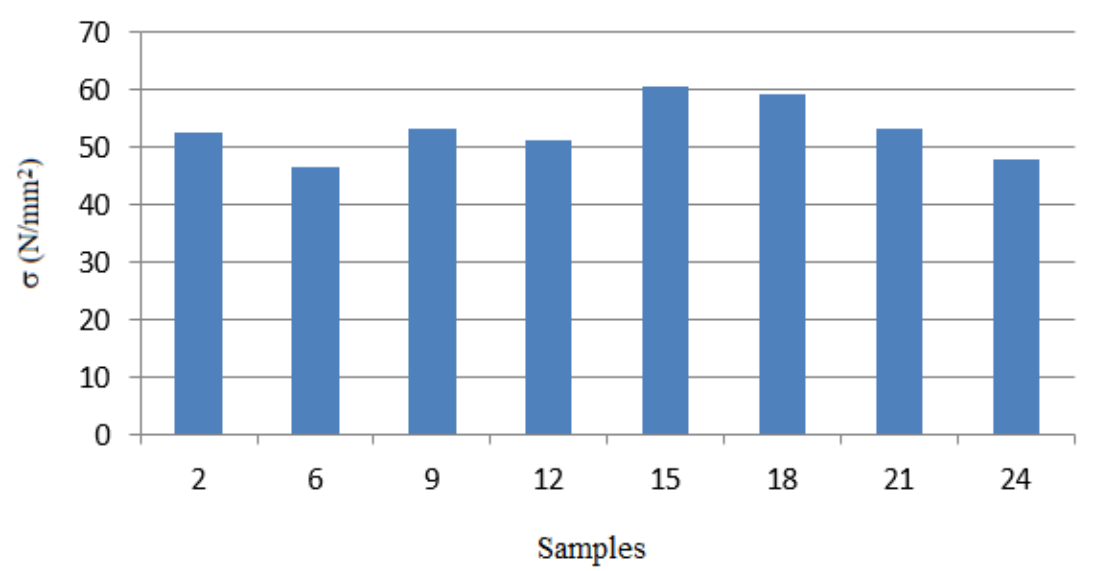

(b)

Figure 5. Stress-strain of (a) sample 1, 2, 3 and 4, (b) sample 2, 6, 9, 12, 15, 18, 21 and 24

\section{CONCLUSIONS}

Epoxy resins are in the family of high viscosity thermoset plastics. Various diluents are added to reduce their viscosity in industry, as their application alone creates difficulties due to their high viscosity. In this study, by adding reactive and non-reactive diluents to epoxy resin, conditions providing optimum mechanical performance that would not critically affect the strength performance were determined. For this purpose, experiments were carried out in different proportions by mass based on the amount of epoxy resin using DE as a reagent and BA as a non-reactive. Considering the test results obtained as a result of the studies under the name of modification of epoxy resin, it was seen that using EDA as a hardener increased the mechanical performance. The 
use of BA as a diluent also reduces the mechanical performance compared to the use of DE. Since there are epoxy groups in DE, the amount of hardener added is added according to the amount of epoxy resin and DE in the mixture. Therefore, the number of epoxy groups in the mixture increases, and the amine groups in the hardener are cross-linked with more epoxy groups. This affects the mechanical performance positively. The results show that the optimum composition that does not dramatically affect the mechanical performance of the epoxy resin is the composition containing 7.5\% DE and 10\% EDA. In some applications in the industry, there is a need for thermoset plastics that provide satisfactory results in terms of both flexible and mechanical performance. According to the mechanical test results, using DE and BA together reduces the mechanical performance of the epoxy sample but increases the elongation performance. When the trials where both diluents were used together are compared, it is seen that the addition of 10\% DGE and 10\% BA increases the elongation performance critically. When this mixture is cured with EDA, the elongation performance increases, but its mechanical performance drops critically. When the same mixture is cured with DETA, optimum mechanical performance and elongation performance is achieved. The composition containing 10\% DE, 10\% BA and 10\% DETA meets the desired flexibility and mechanical performance when high flexibility performance and moderate mechanical performance are required from epoxy resin.

\section{REFERENCES}

[1] Lee, Ch. \& Neville, K. (1973). Spravochnoye rukovodstvo po epoksidnym smolam (Handbook of Epoxy Resins). Izd. Energiya.

[2] Andreyevskaya, G.D. (1966). Vysokoprochnye orientirovannye stekloplastiki (High Strength Oriented Glass-Fibre Reinforced Plastics). Izd. Lauka.

[3] Qian, J. W., Miao, Y. M., Zhang, L. \& Chen, H. L. (2002). Influence of viscosity slope coefficient of CA and its blends in dilute solutions on permeation flux of their films for MeOH/MTBE mixture, J. Membr. Sci. 203 (1-2), 167-173.

[4] Shaw, S.J. (1993). Additives and modifiers for epoxy resins, in Chemistry and Technology of Epoxy Resins, in: B. Ellis (Ed.), Springer Science + Business Media, Dordrecht, 117-143.

[5] Ozeren Ozgul, E. \& Ozkul M.H. (2018). Effects of epoxy, hardener, and diluent types on the workability of epoxy mixtures, Construction and Building Materials, 158, 369-377.

[6] Blakhman, Ye. M., Skrylova, L.V., Pozamantir, A.G. \& Rosentuler, Sh.M. (1965). Epoksidnye smoly na osnove mnogoatomnykh spirtov iikh primeneniye (Epoxy Resins

[7] Prepared from Polyhydric Alcohols and their Application). LDNTP. Kessenikh, R. M., Korshunova, L.A. \& Petrov, A.V. (1972). Vysokomol. soyed. AI4, 416 (Translated in Polymer Sci. U.S.S.R. 14, 2, 466).

[8] Matejka, L., Dusek, K. \& Dobas I. (1985). Curing of Epoxy Resins with Amines. Polymer Bulletin, 14, 309315.

[9] Maiorana, A., Yue, L. \& Manas-Zloczower, I., Gross, R. (2016). Structure-property relationships of a biobased reactive diluent in a bio-based epoxy resin, J. Appl. Polym. Sci. 43635, 1-8.

[10] Urbaczewski-Espuche, E., Galy, J., Gerard, J., Pascault, J. \& Sautereau, H. (1991). Influence of chain flexibility and crosslink density on mechanical properties of epoxy/amine networks. Polym Eng Sci, 31(22), 1572-1580. 